\title{
IMPLEMENTASI PRINSIP BAGI HASIL DAN MANAJEMEN RISIKO DALAM PRODUK-PRODUK PEMBIAYAAN PERBANKAN SYARIAH DI KOTA MALANG
}

\author{
Abbas Arfan \\ Universitas Islam Negeri Maulana Malik Ibrabim Malang \\ abunawalrajwa@gmail.com, \\ Saifullah \\ Universitas Islam Negeri Maulana Malik Ibrabim Malang \\ saifullabdebab@yahoo.co.id \\ Fakhruddin \\ Universitas Islam Negeri Maulana Malik Ibrabim Malang \\ fakhruddinsyarief@yahoo.co.id
}

\begin{abstract}
The aims of this research is to determine the profit and loss sharing implement its principles on the products of sharia banking finance, the risk management implementation on the products of sharia banking finance and the constraints faced by sharia banking in Malang. This research used statute approach to analyze and to verify data from field research, based on fatwa DSN-MUI and regulation of Bank Indonesia. Method of data collections using questionaires, and analized by interactive analysis and descriptive-quantitative method. The result are the implementation of profit and loss sharing principles on the products of sharia finance in the form of mudlarabah and musyarakah are not well implemented as regulated in fatwa of DSNMUI. The implementation of risk management generally implemented as regulated in Bank Indonesia, but the lack of understanding and knowledge in society about its contracts are caused by the unexperienced human resources.
\end{abstract}

Keywords: Profit Sharing, Risk Management, Sharia Banking.

\begin{abstract}
Abstrak
Tujuan penelitian ini untuk mengetahui implementasi prinsip bagi hasil dalam produkproduk pembiayaan, manajemen risiko serta kendala yang dibadapi perbankan syariah di Kota Malang. Melalui pendekatan statute aprroach, akan diannalisis dan diverifikasi data lapangan dengan fatwa DSN-MUI dan regulasi Bank Indonesia. Teknik pengumpulan data menggunakan angket yang dianalisis dengan model interaktif dan deskriptif-kuantitatif. Kesimpulan penelitian ini, implementasi prinsip bagi hasil dalam produk-produk pembiayaan dengan akad mudharabah dan musyarakah di perbankan syariah belum semuanya sesuai syariat Islam dan fatwa DSN-MUI, implementasi manajemen risiko secara umum sudah sesuai dengan regulasi Bank Indonesia, rendahnya pemahaman dan pengetahuan masyarakat terhadap pembiayaan dengan akad mudharabah dan musyarakah, implementasi menejemen resiko terkendala sumber daya manusia yang kurang berpengalaman.
\end{abstract}

Kata Kunci: Bagi Hasil, Manajemen Risiko, Perbankan Syariah.

Permalink/DOI: http://dx.doi.org/10.18326/infsl3.v10i1.213-238 


\section{Pendahuluan}

Secara garis besar fungsi bank syariah tidak berbeda dengan bank konvensional, yakni sebagai lembaga intermediasi (intermediary institution) yang mengerahkan dana dari masyarakat dan menyalurkan kembali dana-dana tersebut kepada masyarakat yang membutuhkannya dalam bentuk fasilitas pembiayaan (kredit). Sedangkan perbedaan pokoknya terletak dalam jenis keuntungan yang diambil bank dari transaksi-transaksi yang dilakukannya. Bila bank konvensional mendasarkan keuntungannya dari pengambilan bunga, maka bank syariah dari apa yang disebut sebagai imbalan, baik berupa jasa (fee-based income) maupun mark-up atau profit margin, serta bagi hasil (profit sharing and loss dan Revenue Sharing) (Arfan, 2012: 109).

Perkembangan bank syariah di Indonesia sejak munculnya di tahun 90-an sampai sekarang menunjukkan perkembangan yang signifikan. Dalam statistik perbankan syariah terakhir (laporan Oktober 2013) yang dirilis Bank Indonesia (BI) pada tanggal 1202-2014 dalam penyaluran dana (pembiayaan/kredit) perbankan syariah kepada para nasabah dengan prinsip bagi hasil pada akad mudharabah dan musyarakah terjadi peningkatan yang signifikan. Total pembiayaan akad mudharabah pada 2007 sebesar Rp. 5,578 miliar, 2008: 6,205 miliar, 2009: 8,631 miliar, 2010: 8,631 miliar, 2011: 10,229 miliar, 2012 (Desember): 12,023 miliar, dan 2013 (Oktober): 13,664 miliar. Begitu juga pada akad musyarakah terjadi peningkatan yang signifkan, bahkan kedua akad itu selalu 3 besar dengan akad murabahah (Bank Indonesia, 2013: 18). Peningkatan ini menggugah peneliti untuk meneliti lebih jauh dengan studi empiris tentang "impelementasi bagi hasil dan manajemen risiko dalam produk-produk pembiayaan perbankan syariah di kota Malang." Alasan dipilihnya kota Malang Jawa Timur, karena dalam statistik perbankan syariah diperoleh data bahwa Jawa Timur menempati urutan ketiga besar dalam serapan dana pembiayaan setelah DKI Jakarta dan Jawa Barat. Sedangkan untuk wilayah Jawa Timur posisi kota Malang menempati urutan kedua tertinggi setelah Surabaya yang menempati urutan pertama dan kota Kediri pada urutan ketiga (Bank Indonesia, 2013: 49-51). 
Oleh karena itu, rumusan masalah dalam penelitian ini dikontruksikan dalam tiga butir pertanyaan sebagai berikut: 1) bagaimana implementasi prinsip bagi hasil dalam produk-produk pembiayaan perbankan syariah di kota Malang?; 2) bagaimana implementasi manajemen risiko dalam produk-produk pembiayaan perbankan syariah di kota Malang? dan; 3) apa kendalakendala yang dihadapi perbankan syariah Kota Malang dalam mengimplementasikan prinsip bagi hasil dan manajemen risiko dalam produk-produk pembiayaan?

Diantara penelitan terkait prinsip bagi hasil adalah penelitian yang dilakukan oleh M. Ali Wafa, mahasiswa S1 Fakultas Ekonomi Jurusan Manajemen Universitas Islam Negeri (UIN) Maulana Malik Ibrahim tahun 2012 yang berjudul "Perhitungan Nisbah Bagi Hasil Dalam Pembiayaan Mudharabah Pada PT. Bank Syari'ah Mandiri Cabang Malang”. Penelitiannya diklasifikasikan ke dalam penelitian kualitatif dengan menggunakan metode desktiptif. Model analisis data yang digunakan yaitu model analisis interaktif yang dikembangkan oleh Miles dan Huberman yang terdiri dari reduksi data, penyajian data, dan penarikan kesimpulan dengan metode sistem rata-rata dan sistem efektif. Diantara hasil penelitiannya adalah bahwa dalam pembiayaan mudharabah muthlaqah Bank Syariah Mandiri Cabang Malang memberikan fasilitas dan otoritas serta hak sepenuhnya kepada nasabah/mudharib untuk melakukan usaha dan mengelola dana yang diperoleh dari pembiayaan mudharabah ini sesuai dengan yang diinginkannya dan hal tersebut akan disebutkan dalam perjanjian atau akad/ kontrak yang disepakati oleh kedua belah pihak (Wafa, 2012: xvii).

Penelitian lain yang juga terkait dengan prinsip bagi hasil dalam pembiayaan perbankan syariah adalah penelitian Teguh Thayalisa, mahasiswa S1 Fakultas Ekonomi Jurusan Manajemen UIN Maulana Malik Ibrahim tahun 2011 yang berjudul "Proses Pelaksanaan Pembiayaan Mudharabah dan Perhitungan Bagi Hasil (Studi Pada PT.BPRS Bumi Rinjani Batu)" dengan jenis penelitian kualitatif dengan pendekatan deskriptif. Sedangkan dalam pengumpulan datanya menggunakan tiga metode yaitu metode wawancara, metode dokumentasi, metode observasi atau pengamatan. Adapun temuannya adalah bahwa salah satu pembiayaan yang dilakukan 
PT. BPRS Bumi Rinjani Batu adalah pembiayaan Mudharabah dan proses pelaksanaannya sebagai berikut: Inisiasi. sosialisasi, analisa terhadap calon nasabah dengan menggunakan analisis 5 C (Character, Capital, Capacity, Condition Economy, Collateral). Proses selanjutnya realisasi, pembinaan atau pemantauan, dan yang terakhir adalah pelunasan. Dalam perhitungan bagi hasil yang diterapkan adalah sistem perhitungan bagi hasil atau profit sharing dimana perhitungan keuntungan dihitung setelah pendapatan dikurangi biaya pengelolaan dana atau dengan kata lain laba bersih. Besar kecilnya nisbah bagi hasil ini dilakukan dengan menggunakan persentase yang ditentukan oleh pihak bank (antara 2,5\% - 2,8\%) dan perbandingan, misalkan $25: 75$. Laba yang diterima oleh bank dapat disetorkan setiap bulan, 3 bulan atau 4 bulan. Hal ini semua tergantung pada kesepakatan awal (Thayalisa, 2012: xvi).

Kedua penelitian tersebut di atas, yaitu M. Ali Wafa dan Teguh Thayalisa berbeda dengan penelitian ini, walau sama dalam hal pembahasan prinsip bagi hasil, namun kedua penelitian di atas terfokus pada pembiayaan dengan akad mudharabah saja dengan objek penelitian pada salah satu bank syariah di Malang Raya. Sedangkan penelitian ini membahas implementasi prinsip bagi hasil dalam pembiayaan dengan akad mudharabah dan musyarakah di beberapa bank syariah di kota Malang dengan menjadikan fatwafatwa DSN-MUI sebagai acuan. Di samping itu, kedua penelitian tersebut tidak menganalisis implementasi manajemen risiko sebagaimana penelitian ini.

\section{Metode Penelitian}

Penelitian ini termasuk jenis penelitian kualitatif, karena data yang dikumpulkan berupa data lapangan hasil angket tentang implememtasi prinsip bagi hasil dan manajemen risiko dalam produk-produk pembiayaan perbankan syariah di kota Malang dan dianalisis secara induktif dengan cara memverifikasi data lapangan tentang prinsip bagi hasil dengan fatwa Dewan Syariah Nasional-Majelis Ulama Indonesia (DSN-MUI) tentang pembiayaan mudharabah dan musyarakah. Sedangkan data lapangan tentang manajemen risiko didiverifikasi dengan Peraturan Bank Indonesia 
(PBI) tentang penerapan manajemen risiko bagi perbankan syariah. Format desain dari penelitian kualitatif ini adalah desain kualitatif verifikatif, sebuah upaya pendekatan induktif terhadap seluruh proses penelitian yang akan dilakukan (Bungin, 2001: 62). Pendekatan yang akan digunakan dalam peneltian ini adalah pendekatan perundangundangan (statute aprroach), karena penelitian hukum baik normatif atau empiris tidak dapat melepaskan diri dari pendekatan perundang-undangan.

Teknik penggumpulan data menggunakan instrumen pengumpulan data berupa angket yang berupaya mengungkap data tentang implementasi prinsip bagi hasil dan manajemen risiko dalam produk-produk pembiayaan perbankan syariah di Kota Malang serta kendala-kendala yang pernah terjadi dalam implementasi tersebut. Jumlah Bank Syariah di Kota Malang berjumlah delapan Bank, yaitu: 1) Bank Syariah Mandiri (BSM); 2) Bank Tabungan Negara (BTN) Syariah; 3) Bank Muamalat; 4) Bank Rakyat Indonesia (BRI) Syariah; 5) Bank Negara Indonesia (BNI) Syariah; 6) Bank Panin Syariah; 7) Bank Mega Syariah dan; 8) Bank CIMB Niaga Syariah, namun yang dijadikan sampel dalam penelitian ini hanya lima bank syariah dari delapan bank syariah tersebut (61,5\%), yaitu: BSM, BTN Syariah, Bank Muamalat, BRI Syariah dan BNI Syariah. Penentuan sampel dalam penelitian ini menggunakan teknik pengambilan sampel dengan teknik non probability sampling, yaitu: sebuah teknik di mana semua anggota populasi tidak mendapat peluang yang sama untuk dijadikan sampel, karena pertimbangan-pertimbangan tertentu.

Sedangkan jenis pertanyaan angket dalam penelitian ini adalah kombinasi antara jenis pertanyaan yang berstruktur dan terbuka, karena pertanyaan-pertanyaan yang akan ditanyakan dalam angket ada yang memiliki alternatif jawaban yang pasti (terstruktur), seperti: ya atau tidak dan ada yang masih relatif (terbuka) atau tidak terikat dengan alternatif jawaban yang disediakan, yaitu berupa isian jawaban yang bebas sesuai pendapat dan kondisi responden masing-masing. Sedangkan teknik analisis data yang digunakan dalam penelitian ini adalah model analisis data yang digunakan yaitu model analisis interaktif yang dikembangkan oleh Miles dan Huberman yang terdiri dari tiga langkah, yaitu: data reduction (reduksi data), data display 
(penyajian data) dan conclusion drawing/verification (penarikan kesimpulan) (Sugioyo, 2009: 246-252).

\section{Implementasi Prinsip Bagi Hasil dalam Pembiayaan Akad Mudharabah}

Adapun hasil pengumpulan data terkait dengan implementasi prinsip bagi hasil dalam produk-produk pembiayaan dengan akad mudharabah pada Bank Syariah (BS) di Kota Malang dapat dilihat pada tabel berikut:

\section{Tabel 1.}

\section{Implementasi Akad Mudharabah}

\begin{tabular}{lll}
\hline NO & PERTANYAAN & PERSENTASE JAWABAN \\
\hline
\end{tabular}

BS bapak/ ibu memperlakukan pembiayaan Mudharabah

1 kepada mudharib sebagai piutang mudharib atau modal

a. Piutang $60 \%$

b. Modal $40 \%$ dalam usaha Mudharib?

Apakah BS bapak/ ibu selalu mensyaratkan agar usaha yang dijalankan telah beroperasi minimal 3 tahun?
a. Selalu $60 \%$
b. Tidak $20 \%$
c. Kadang-kadang $20 \%$

Apakah dalam akad

3 mudharabah disyaratkan adanya jaminan tertentu?

a. Ya $100 \%$

b. Tidak $0 \%$

Apakah BS bapak/ ibu membebankan biaya survey dan studi kelayakan usaha kepada mudharib (nasabah)?

b. Tidak $60 \%$

c. Kadang- kadang $0 \%$ Apakah BS bapak/ ibu turut

a. Selalu $60 \%$

5 serta melakukan pengawasan

b. Tidak $0 \%$ dan pembinaan usaha?

c. Kadang- kadang $40 \%$

Sistem bagi hasil apakah

a. Revenue Sharing $100 \%$

6 yang digunakan dalam akad mudharabah?

b. Profit Sharing $0 \%$ 
Apakah penetapan nisbah bagi

7 hasil yang dipilih disepakati dalam akad?

Dalam bentuk apa bagi hasil

8 yang diminta BS bapak/ ibu kepada mudharib?

9 Jika dalam bentuk prosentase ; berapa jumlah persentase bagi hasilnya?

10 Darimanakah laba atau rugi mudharabah diketahui BS bapak/ ibu?

11 Bagaimana sistem angsuran atau pembayaran pembiayaan dari mudharib kepada BS bapak/ ibu?

12 Apabila terjadi kerugian dalam usaha pengelolaan dana mudharabah; apakah BS bapak/ ibu pernah menanggung kerugian tersebut?

13 Berapa jangka waktu rata-rata pembiayaan mudharabah? a. Ya $100 \%$

b. Tidak $0 \%$

a. Nominal $20 \%$

b. Persentase $80 \%$

a. Bank $70 \%$ : Nasabah $30 \%$ $0 \%$

b. Bank $60 \%$ : Nasabah $40 \%$ $25 \%$

c. Relatif $75 \%$

a. Laporan pengelolaan dana mudharib $80 \%$

b. Laporan hasil perhitungan versi BS $20 \%$

c. Lainnya $0 \%$

a. Angsuran bulanan/harian pokok dan bagi hasil $100 \%$

b. Angsuran bulanan/harian bagi hasil saja dan angsuran pokok di akhir akad $0 \%$

c. Angsuran bulanan/harian pokok dan bagi hasil di akhir akad $0 \%$

a. Pernah

b. Belum pernah

c. Lainnya,

a. $3-6$ bulan $0 \%$

b. $6-12$ bulan $0 \%$

c. $12-36$ bulan $60 \%$

d. Lainnya $40 \%$ 
14 Berapa jumlah rata-rata per pembiayaan mudharabah?

15 Jenis-jenis usaha apa sajakah yang dibiayai dengan akad mudharabah? (urutkan menurut jumlah nasabah)
a. Dibawah Rp 10.000.000,- $0 \%$
b. Rp 10.000.000,- s/d Rp Rp 50.000.000,- $20 \%$
c. Rp 50.000.000,- s/d Rp 100.000.000,- $20 \%$
d. Di atas Rp 100.000.000,- $60 \%$

Perdagangan $60 \%$; Lainnya 40 $\%$

Dari tabel di atas dapat dilakukan analisis terkait implementasi prinsip bagi hasil dalam akad mudharabah dengan mengacu kepada fatwa DSN-MUI No. 07/DSN-MUI/IV/2000 tentang pembiayaan mudharabah (Qiradh) dan kodifikasi produk perbankan syariah BI tahun 2008. Analisis berikut ini akan disesuaikan dengan urutan nomor kuiseoner sebagaimana table di atas, namun yang akan dianalisis dalam ringkasan hasil penelitian ini hanya tiga hal yang tidak sesuai dengan fatwa DSN-MUI:

a. Dana pembiayaan dengan akad mudharabah yang diberikan Bank Syariah (BS) kepada nasabah (mudharib) seharusnya dianggap sebagai modal usaha dan bukan piutang, tetapi ternyata 60 \% BS di Kota Malang masih mengangapnya sebagai piutang. Hal ini jelas bertentangan dengan fatwa DSN-MUI No. 07/DSNMUI/IV/2000 tentang pembiayaan mudharabah (Qiradh) yang menegaskan bahwa akad mudharabah adalah "akad kerjasama suatu usaha antara dua pihak di mana pihak pertama (malik, shahib al-mal, LKS) menyediakan seluruh modal, sedang pihak kedua ('amil, mudharib, nasabah) bertindak selaku pengelola, dan keuntungan usaha dibagi diantara mereka sesuai kesepakatan yang dituangkan dalam kontrak." Hal ini diperkuat juga dengan kodifikasi produk perbankan syariah yang diterbitkan BI bahwa dalam pembiayaan dengan akad mudharabah bank bertindak sebagai pemilik dana (shabibul maal) yang menyediakan dana 
dengan fungsi sebagai modal kerja, dan nasabah bertindak sebagai pengelola dana (mudharib) dalam kegiatan usahanya. Begitu juga dalam Kompilasi Hukum Ekonomi Syariah (KHES) yang menegaskan bahwa pemerian dana kepada nasabah harus berupa modal (baik berupa uang atau barang) dan bukan berupa piutang. Oleh karena itu, jika pemberian dana itu dianggap sebagai piutang atau hutang nasabah kepada BS, maka kesepakatan persentase bagi hasil yang dibuat saat kontrak akad pembiayaan mudharbah bisa dihukumi sebagai riba yang diharamkan Islam. Belum lagi, jika pemberian dana dari BS kepada nasabah (mudharib) digolongkan sebagai piutang, maka tidak ada bedanya dengan bank konvensional dengan sistem bunga yang pola hubungan antara pihak bank dengan nasabah adalah debitur dan kreditur, sedangkan hubungan antara bank dan nasabah dalam perbankan syariah adalah hubungan mitra kerja. Oleh karena itu, modal mudharabah tidak boleh berupa suatu hutang yang dipinjam mudharib pada saat dilanjutkan kontrak mudharabah, karena dalam kontrak semacam ini investor (yang dalam hal ini adalah perbankan syariah) dapat dengan mudah menggunakan mudharabah sebagai alat untuk memperoleh kembali hutangnya sekalian mengambil untung darinya. Mengambil untung dari suatu hutang sebagai riba yang diharamkan dalam hukum Islam. Dari sekian empat Mazhab Fiqh tak satupun yang mengizinkan suatu kontrak dimana kreditur meminta debitur untuk menjalankan mudharabah berdasarkan pengertian bahwa modal kongsi adalah hutang calon mudharib kepada investor;

b. Terkait dengan pembebanan biaya survey dan studi kelayakan usaha kepada mudharib (nasabah) lewat penelitian ini ditemukan bahwa $40 \%$ perbankan syariah di Kota Malang melakukan hal tersebut, namun $60 \%$ tidak melakukannya. Pembebanan biaya survey dan studi kelayakan usaha kepada mudharib tidak diatur secara eksplisit dalam fatwa DSN-MUI atau Peraturan Bank Indonesia (PBI), maka sangat wajar jika terdapat perbedaan kebijakan antara masing-masing perbankan syariah, namun jika mengacu kepada fiqh, maka seluruh biaya pra kontrak mudharabah adalah menjadi beban pelaku, seperti 
biaya survey dan studi kelayakan usaha kepada mudharib yang lakukan pihak bank adalah menjadi kewajiban bank sendiri, seperti halnya biaya transportasi nasabah dari rumah ke bank adalah juga menjadi kewajiban nasabah sendiri. Lain halnya, jika biaya itu dikeluarkan setelah terjadi kontrak kesepakatan akad mudharabah dan terkait dengan akad mudharbah, seperti biaya operasional kegiatan usaha yang didanai lewat akad mudharabah, maka menjadi kewajiban nasabah (mudharib) seperti dijelaskan oleh DSN-MUI bahwa biaya operasional dibebankan kepada mudharib.

c. Adapun bentuk bagi hasil yang diminta BS kepada nasabah (mudharib) adalah sebagaimana hasil data lapangan, yaitu 20 $\%$ dalam bentuk nominal dan $80 \%$ dalam bentuk persentase. Padahal seharusnya sesuai fatwa DSN-MUI dinyatakan bahwa bagi hasil pembiayaan akad mudharabah adalah dalam bentuk persentase, sebagaimana bunyi teks dalam fatwa DSN-MUI: "bagian keuntungan proporsional bagi setiap pihak harus diketahui dan dinyatakan pada waktu kontrak disepakati dan harus dalam bentuk prosentasi (nisbah) dari keuntungan sesuai kesepakatan. Perubahan nisbah harus berdasarkan kesepakatan." Keharusan bentuk bagi hasil dalam akad mudharabah berupa nisbah (persentase) bagi hasil dan bukan dalam bentuk nominal adalah dikarenakan jika dalam bentuk nominal, maka tergolong riba yang diharamkan Islam. Disamping itu, jika dalam bentuk nominal dapat merugikan nasabah (mudharib) disaat nasabah mengalami kerugian atau mendapat sedikit keuntungan, juga bias merugikan pihak bank disaat nasabah mendapat keuntungan yang banyak.

\section{ImplementasiPrinsipBagiHasildalam Pembiayaan AkadMusyarakah}

Adapun hasil pengumpulan data terkait dengan implementasi prinsip bagi hasil dalam produk-produk pembiayaan dengan akad musyarakah pada Bank Syariah (BS) di Kota Malang dapat dilihat pada table berikut: 
Tabel 2.

Implementasi Akad Musyarakah

\begin{tabular}{|c|c|c|}
\hline $\mathrm{NO}$ & PERTANYAAN & PERSENTASE JAWABAN \\
\hline 1 & $\begin{array}{l}\text { Apakah BS bapak/ ibu } \\
\text { memperlakukan pembiayaan } \\
\text { musyarakah kepada mitra } \\
\text { sebagai piutang atau modal? }\end{array}$ & $\begin{array}{l}\text { a. Piutang } 20 \% \\
\text { b. Modal } 80 \%\end{array}$ \\
\hline 2 & $\begin{array}{l}\text { Apakah BS bapak/ ibu selalu } \\
\text { mensyaratkan agar usaha yang } \\
\text { dijalankan telah beroperasi } \\
\text { minimal } 3 \text { tahun? }\end{array}$ & $\begin{array}{l}\text { a. Selalu } 60 \% \\
\text { b. Tidak } 20 \% \\
\text { c. Kadang-kadang } 20 \%\end{array}$ \\
\hline 3 & $\begin{array}{l}\text { Apakah dalam akad } \\
\text { musyarakah disyaratkan } \\
\text { adanya jaminan tertentu? }\end{array}$ & $\begin{array}{l}\text { a. Ya } 100 \% \\
\text { b. Tidak } 0 \%\end{array}$ \\
\hline 4 & $\begin{array}{l}\text { Apakah BS bapak/ ibu } \\
\text { membebankan biaya survey } \\
\text { dan studi kelayakan usaha } \\
\text { kepada mitra (nasabah)? }\end{array}$ & $\begin{array}{l}\text { a. Selalu } 20 \% \\
\text { b. Tidak } 80 \% \\
\text { c. Kadang- kadang } 0 \%\end{array}$ \\
\hline 5 & $\begin{array}{l}\text { Sejauhmana keterlibatan } \\
\text { BS bapak/ ibu dalam } \\
\text { musyarakah? }\end{array}$ & $\begin{array}{l}\text { a. Terlibat di dalam manajemen } \\
0 \% \\
\text { b. Hanya melakukan } \\
\text { pengawasan dan pembinaan } \\
100 \% \\
\text { c. Menyerahkan sepenuhnya } \\
\text { kepada mitra } 0 \%\end{array}$ \\
\hline 6 & $\begin{array}{l}\text { Bagaimana perlakuan BS } \\
\text { bapak/ ibu apabila terjadi } \\
\text { kerugian dalam musyarakah } \\
\text { akibat kelalaian atau } \\
\text { kesalahan mitra pengelola } \\
\text { usaha musyarakah? }\end{array}$ & $\begin{array}{l}\text { a. Ditanggung oleh pengelola } \\
\text { usaha musyarakah } 80 \% \\
\text { b. Ditanggung bersama antara } \\
\text { BS dan pengelola usaha } 20 \% \text {. }\end{array}$ \\
\hline 7 & $\begin{array}{l}\text { Sistem bagi hasil apakah } \\
\text { yang digunakan dalam akad } \\
\text { musyarakah? }\end{array}$ & $\begin{array}{l}\text { a. Revenue Sharing } 80 \% \\
\text { b. Profit Sharing } 0 \% \\
\text { (tdk menjawab } 20 \% \text { ) }\end{array}$ \\
\hline 8 & $\begin{array}{l}\text { Apakah penetapan sistem bagi } \\
\text { hasil yang dipilih disepakati } \\
\text { dalam akad? }\end{array}$ & $\begin{array}{l}\text { a. Ya } 100 \% \\
\text { b. Tidak } 0 \%\end{array}$ \\
\hline
\end{tabular}


9 Dalam bentuk apa bagi hasil

a. Nominal $0 \%$ yang diminta BS bapak/ ibu

b. Persentase 100\% kepada mudharib?

10 Jika dalam bentuk prosentase; apakah bagi hasil selalu

a. Ya $60 \%$ didasarkan pada besaran

b. Tidak $40 \%$ modal masing-masing?

11 Darimanakah laba atau rugi musyarakah diketahui BS bapak/ ibu?

a. Laporan pengelolaan dana mudharib $60 \%$

b. Laporan hasil perhitungan versi BS $40 \%$

c. Lainnya $0 \%$

12 Bagaimana sistem angsuran atau pembayaran pembiayaan musyarakah kepada BS bapak/ ibu?

a. Angsuran bulanan/harian pokok dan bagi hasil $40 \%$

b. Angsuran bulanan/harian bagi hasil saja dan angsuran pokok di akhir akad $40 \%$

c. Angsuran bulanan/harian pokok dan bagi hasil di akhir akad $0 \%$

d. Angsuran bulanan/harian bagi hasil saja dan angsuran pokok tergantung kesepakatan $20 \%$

13 Berapa jangka waktu rata-rata

a. 3 - 6 bulan $0 \%$ pembiayaan musyarakah?

b. $6-12$ bulan $40 \%$

c. 12 - 36 bulan $40 \%$

d. Lainnya $20 \%$

14 Berapa jumlah rata-rata per

a. Dibawah Rp 10.000.000,- 0 \% pembiayaan musyarakah?

b. Rp 10.000.000,- s/d Rp Rp 50.000.000,- $0 \%$

c. Rp 50.000.000,- s/d Rp 100.000.000,- $0 \%$

d. Di atas Rp 100.000.000,- 100 $\%$

15 Jenis-jenis usaha apa sajakah Perdagangan $60 \%$; Lainnya 40 yang dibiayai dengan akad $\%$ musyarakah? (urutkan menurut jumlah nasabah) 
Dari tabel di atas dapat dilakukan analisis terkait implementasi prinsip bagi hasil dalam akad musyarakah dengan mengacu kepada fatwa DSN-MUI No. 08/DSN-MUI/IV/2000 tentang pembiayaan musyarakah dan kodifikasi produk perbankan syariah BI tahun 2008. Analisis berikut ini akan disesuaikan dengan urutan nomor kuiseoner sebagaimana table di atas, namun yang akan dianalisis dalam ringkasan hasil penelitian ini hanya tiga hal yang tidak sesuai dengan fatwa DSN-MUI:

a. Dana pembiayaan dengan akad musyarakah yang diberikan Bank Syariah (BS) kepada nasabah (mitra) seharusnya dianggap sebagai modal usaha dan bukan piutang, tetapi ternyata $20 \%$ BS di Kota Malang masih mengangapnya sebagai piutang. Hal ini jelas bertentangan dengan fatwa DSN-MUI No. 08/DSNMUI/IV/2000 tentang pembiayaan musyarakah (dengan analisis yang sama dengan mudharabah di atas);

b. Terkait dengan pembebanan biaya survey dan studi kelayakan usaha kepada nasabah lewat penelitian ini ditemukan bahwa $20 \%$ perbankan syariah di Kota Malang melakukan hal tersebut (berbeda dengan kasus dalam akad mudharabah yang mencapai $40 \%$ ), dan $80 \%$ tidak melakukan pembebanan biaya survey dan studi kelayakan usaha kepada nasabah (dalam akad mudahrabah mancapai 60 \%). Pembebanan biaya survey dan studi kelayakan usaha kepada nasabah tidak diatur secara eksplisit dalam fatwa DSN-MUI atau Peraturan Bank Indonesia (PBI), maka sangat wajar jika terdapat perbedaan kebijakan antara masing-masing perbankan syariah, namun jika mengacu kepada fiqh, maka seluruh biaya pra kontrak musyarakah adalah menjadi tanggungjawab masing-masing;

c. Apabila terjadi kerugian dalam musyarakah akibat kelalaian atau kesalahan mitra pengelola usaha musyarakah, maka (menurut data table di atas) $80 \%$ perbankan syariah di Kota Malang membebankan tanggungjawab kepada pengelola usaha musyarakah dan hanya $20 \%$ yang menanggung bersama antara pengelola usaha dan BS. Menurut fatwa DSN-MUI terkait dengan kerugian dalam usaha musyarakah adalah menjadi tanggungjawab bersama semua mitra musyarakah sesuai modal 
masing-masing. Adapun kerugian yang disebabkan akibat kelalaian atau kesalahan mitra pengelola usaha musyarakah adalah menjadi tanggungjawab siapa, ternyata tidak disebut dengan jelas dalam fatwa DSN-MUI, akan tetapi dalam fatwa DSN-MUI dijelaskan bahwa setiap mitra memberi wewenang kepada mitra yang lain untuk mengelola aset dan masing-masing dianggap telah diberi wewenang untuk melakukan aktifitas musyarakah dengan memperhatikan kepentingan mitranya, tanpa melakukan kelalaian dan kesalahan yang disengaja. Artinya, siapapun yang lalai (BS atau pengelola) selama tidak disengaja, maka tidak bisa disalahkan, karena telah dapat wewenang untuk bertindak dalam usaha, sehingga kerugian tetap harus ditanggung bersama. Oleh karena itu, dalam hal ini $80 \%$ perbankan syariah di Kota Malang belum mengimplementasikan akad musyarakah sesuai syariah (DSN-MUI);

\section{Implementasi Manajemen Risiko Dalam Produk-ProdukPembiayaan Perbankan Syariah}

Sedangkan hasil pengumpulan data terkait dengan implementasi manajemen risiko dalam produk-produk pembiayaan perbankan syariah di Kota Malang dapat dilihat pada table berikut:

\section{Tabel 3.}

\section{Implementasi Manajemen Risiko}

\begin{tabular}{|c|c|c|c|}
\hline $\mathrm{NO}$ & PERTANYAAN & JAWABAN & $\begin{array}{l}\text { PERSENTASE } \\
\text { JAWABAN }\end{array}$ \\
\hline \multirow{6}{*}{1} & \multirow{6}{*}{$\begin{array}{l}\text { Laporan keuangan } \\
\text { apa sajakah yang } \\
\text { tersedia di BS } \\
\text { bapak/ ibu? }\end{array}$} & a. Neraca & 1. Semua Laporan \\
\hline & & b. Laporan rugi & $(8$ jenis $)=20 \%$ \\
\hline & & laba & 2. Tujuh Laporan \\
\hline & & $\begin{array}{l}\text { c. Laporan arus } \\
\text { kas }\end{array}$ & $20 \%$ \\
\hline & & $\begin{array}{l}\text { d. Laporan } \\
\text { perubahan }\end{array}$ & 3. Lima Laporan = \\
\hline & & $\begin{array}{l}\text { modal } \\
\text { e. Catatan atas } \\
\text { laporan }\end{array}$ & $\begin{array}{l}\text { 4. Dua Laporan = } \\
20 \%\end{array}$ \\
\hline
\end{tabular}


f. keuangan

g. Laporan dana non halal

h. Laporan dana zakat

i. Laporan distribusi hasil usaha (profit distribution) (jawaban bisa lebih dari satu)

2 Laporan keuangan apa sajakah yang disampaikan kepada nasabah dan publik?
a. Neraca
b. Laporan Rugi
Laba
c. Laporan arus kas
d. Laporan
perubahan
modal
e. Catatan atas laporan keuangan
f. Laporan dana non halal
g. Laporan dana zakat
h. Laporan distribusi hasil usaha (profit distribution)
(jawaban bisa lebih dari satu)
1. Semua Laporan (8 jenis) $=0 \%$
2. Tujuh Laporan $=20$ $\%$
3. Lima Laporan $=40$ $\%$
4. Dua Laporan $=20$ $\%$
5. Satu Laporan $=20$ $\%$ 
3 Apakah tersedia

a. Ya

a. Ya $100 \%$

Standard Operation

b. Tidak

b. Tidak $0 \%$

Procedure (SOP)

bagi administrator

keuangan yang jelas

dan baik?

4 Apakah BS bapak/

a. Ya

a. Ya $100 \%$

ibu mempunyai

b. Tidak

b. Tidak $0 \%$ internal auditor?

5 Apakah laporan

a. Ya

a. Ya $100 \%$

keuangan BS bapak/

b. Tidak

b. Tidak $0 \%$

ibu pernah diaudit

oleh akuntan publik

atau eksternal

auditor?

6 Apakah BS bapak/

a. Ya

a. Ya $100 \%$

ibu memiliki Komite

b. Tidak

b. Tidak $0 \%$

Manajemen Risiko

(KMR)?

7 Apakah BS bapak/ ibu memiliki Satuan

a. Ya

a. Ya $100 \%$

Kerja Manajemen

b. Tidak

b. Tidak $0 \%$

Risiko (SKMR)?

8 Apakah KMR dan

a. Tersendiri

a. Tersendiri $100 \%$

SKMR tersebut

dibentuk secara

b. Digabung

b. Digabung $0 \%$

tersendiri atau dengan BUK

digabungkan

c. Lainnya......

dengan Bank Umum

Konvensional (BUK)?

$9 \quad$ Jika digabung

a. Ya

dengan BUK; apakah

b. Tidak

direktur BS bapak/

ibu diikutsertakan

sebagai salah satu

anggota Komite

Manajemen Risiko

BUK? 
10 Apakah BS bapak/ ibu memiliki Dewan Pengawas Syariah (DPS)?

11 Bagaimanakah peran DPS?

12 Seberapa sering DPS dilibatkan dalam mengambil keputusan?

13 Jika jawaban no. 12 adalah "c" atau "d", apa penyebabnya?

14 Apakah DPS selalu melakukan evaluasi atas kebijakan manajemen risiko yang terkait dengan pemenuhan prinsip syariah?
a. Ya
a. Ya $100 \%$
b. Tidak
b. Tidak $0 \%$

a. Sangat penting

a. Sangat penting $80 \%$

b. Penting

b. Penting $20 \%$

c. Tidak penting

d. Sangat tidak penting
a. Semua masalah
a. Semua masalah selalu dilibatkan selalu dilibatkan
b. Hanya jika ada masalah serius
c. Jarang sekali dilibatkan
d. Tidak pernah dilibatkan $60 \%$
b. Hanya jika ada masalah serius $40 \%$
a. kualifikasi dewan kurang memadai

b. komitmen dewan rendah

c. terdapat kendala bersifat teknis

d. Lainnya, 
15 Apakah DPS selalu

a. Ya

a. Ya $100 \%$

mengevaluasi

b. Tidak

b. Tidak $0 \%$

pertanggungjawaban

direksi atas

c. Kadang-kadang

c. Kadang-Kadang 0

pelaksanaan

kebijakan manajemen

risiko yang terkait

dengan pemenuhan

prinsip syariah?

16 Apakah dalam

a. Ya

a. Ya $60 \%$

4 tahun terakhir

b. Tidak

b. Tidak $40 \%$

BS bapak/ ibu

pernah mendapati

kegagalan nasabah

atau pihak lain

dalam memenuhi

kewajiban kepada

BS sesuai perjanjian

yang disepakati?

17 Jika jawaban no.

16 "ya"; berapa

a. Dibawah $5 \%$

b. Antara 5-10\%

a. Dibawah $5 \%=100$

kira-kira rata-rata

c. Diatas $10 \%$

prosentasenya dalam

d. Lainnya......\%

4 tahun terakhir?

18 Apakah dalam 4 tahun

terakhir BS bapak/

a. Ya

a. Ya $40 \%$

ibu pernah ikut

b. Tidak

b. Tidak $60 \%$

menanggung kerugian

usaha nasabah

yang dibiayai dalam

pembiayaan dengan

prinsip bagi hasil?

19 Jika jawaban no.

18 "ya"; berapa

a. Dibawah $5 \%$

b. Antara $5-10 \%$

a. Dibawah $5 \%=50$ $\%$

kira-kira rata-rata

c. Diatas $10 \%$

d. Lainnya = di bawah

prosentasenya dalam

d. Lainnya......\%

$2 \%=50 \%$

4 tahun terakhir? 
20 Apakah dalam 4 tahun terakhir BS bapak/ ibu pernah mendapat tuntutan hukum dari nasabah atau lainnya?

21 Jika jawaban no. 20 "ya"; berapa kira-kira rata-rata prosentasenya dalam 4 tahun terakhir?

22 Apakah dalam 4 tahun terakhir BS bapak/ ibu pernah menuntut secara hukum kepada nasabah pembiayaan atau lainnya?

23 Jika jawaban no. 22 "ya"; berapa kira-kira rata-rata prosentasenya dalam 4 tahun terakhir?

24 Sebelum terbitnya putusan MK Nomor 93/PUU-X/2012; kebanyakan dari sengketasengketa yang terjadi di BS bapak/ ibu diselesaikan melalui.....
a. $\mathrm{Ya}$
a. Ya $60 \%$
b. Tidak
b. Tidak $40 \%$

a. Dibawah $5 \%$

b. Antara 5-10\%

c. Diatas $10 \%$

d. Lainnya.......\%
a. Ya
b. Tidak
a. Ya $20 \%$
b. Tidak $80 \%$
a. Dibawah $5 \%$
a. Dibawah $5 \%=100$
b. Antara 5-10\% $\%$

c. Diatas $10 \%$

d. Lainnya.......\%
a. musyawarah $\quad \mathrm{a}=40 \%$
b. Mediasi $\mathrm{e}=20 \%$ Perbankan $\mathrm{a}, \mathrm{b} \& \mathrm{f}=20$

c. Badan Arbitrase Syariah Nasional

d. Lembaga Arbitrase lain

e. Pengadilan Umum

f. Pengadilan Agama 
25 Setelah terbitnya putusan MK Nomor 93/PUU-X/2012; kebanyakan dari sengketasengketa yang terjadi di BS bapak/ ibu diselesaikan melalui.....

26 Apakah BS

bapak/ ibu selalu melaporkan laporan profil risiko kepada Bank Indonesia(BI) secara rutin setiap triwulanan?

27 Apakah dalam 4 tahun terakhir, Bank Indonesia (BI) pernah meminta BS bapak/ ibu melaporkan laporan profil risiko diluar jadwal triwulanan? a. musyawarah $a=40 \%$

b. Mediasi a, b \& f = 20 Perbankan $\mathrm{f}=40 \%$

c. Badan Arbitrase Syariah Nasional

d. Lembaga Arbitrase lain

e. non Ligitasi lainnya...........

f. Pengadilan Umum

g. Pengadilan Agama
a. Ya
a. Ya $100 \%$

b. Tidak

b. Tidak $0 \%$

Dari tabel di atas dapat dilakukan analisis terkait implementasi manajemen risiko dalam produk-produk pembiayaan perbankan syariah di Kota Malang dengan mengacu kepada Peraturan Bank Indonesia (PBI) nomor 13/23/PBI/2011 tentang "Penerapan Manajemen Risiko Bagi Bank Umum Syariah Dan Unit Usaha Syariah" dan beberapa literatur pendukung terkait manajemen risiko. Analisis berikut ini akan disesuaikan dengan urutan nomor kuiseoner sebagaimana table di atas, namun yang akan dianalisis dalam ringkasan hasil penelitian ini hanya satu hal yang tidak sesuai 
dengan regulasi perbankan, yaitu tentang keterbukaan informasi. Terkait laporan keuangan yang disampaikan kepada nasabah dan publik juga masih rendah, karena tidak ada satupun BS yang melaporkan semua laporan keuangannya, padahal ada $20 \%$ BS yang memiliki laporan keuangan lengkap. Hal ini menunjukan minimnya transparansi (keterbukaan) perbankan syariah kepada nasabahnya, padahal prinsip keterbukaan merupakan prinsip yang penting untuk mencegah terjadinya tindakan penipuan (fraud). Dengan pemberian informasi berdasarkan prinsip keterbukaan ini, maka dapat diantisipasi terjadinya kemungkinan pemegang saham, investor atau stakeholders tidak memperoleh informasi atau fakta material yang ada. Dengan Prinsip keterbukaan (transparency). artinya, bank syariah berkewajiban memberi informasi tentang kondisi dan prospek perbankannya secara tepat waktu, memadai, jelas, dan akurat. Informasi itu juga harus mudah diakses oleh stakeholders sesuai dengan haknya. Hal ini dapat digunakan sebagai dasar bagi mereka untuk menilai reputasi dan tanggung jawab bank syariah. Prinsip ini dimuat dalam ketentuan Pasal 62 ayat (1) Peraturan Bank Indonesia Nomor 8/4/PBI/2006 tentang Pelaksanaan Good Corporate Governance bagi Bank Umum dan Peraturan Bank Indonesia Nomor 11/33/PBI/2009 tentang Pelaksanaan Good Corporate Governance bagi Bank Umum Syariah (BUS) dan Unit Usaha Syariah (UUS).

Kendala-Kendala yang Dihadapi dalam Mengimplementasikan Prinsip Bagi Hasil dan Manajemen Risiko

Ada delapan kendala (pilihan dalam kuisiner) yang mungkin dihadapi oleh perbankan syariah dalam penerapan sistem bagi hasil pada pembiayaan, baik dengan akad mudharabah atau akad musyarakah, yaitu: 1) Belum adanya standar dan panduan yang jelas; 2) Kurangnya sumber daya yang berpengalaman; 3) Tingginya biaya pengelolaan keuangan secara profesional yang sesuai prinsip syariah; 4) Rendahnya kesadaran masyarakat untuk meminta pembiayaan di BS;5) Rendahnya pemahaman dan pengetahuan masyarakat tentang pembiayaan dengan akad mudharabah/ musyarakah; 6) Minimnya dukungan pemerintah; 7) Kalah saing 
oleh Bank Umum Konvensional; 8) Lainya, seperti monitoring pendapatan yg menjadi obyek bagi hasil.

Adapun kendala yang paling banyak (dipilih dalam kuisioner) adalah tiga kendala saja (peringkat sesuai urutan nomor), yaitu: 1) Rendahnya pemahaman dan pengetahuan masyarakat tentang pembiayaan dengan akad mudharabah/ musyarakah; 2) Tingginya biaya pengelolaan keuangan secara profesional yang sesuai prinsip syariah dan; 3) Minimnya dukungan pemerintah.

Sedangkan kendala yang mungkin dihadapi perbankan syariah dalam mengimplementasikan manajemen risiko adalah sebagai berikut: 1) Belum adanya standar dan panduan yang jelas; 2) Kurangnya sumber daya yang berpengalaman; 3) Tingginya biaya pengelolaan keuangan secara profesional sesuai prinsip syariah dan; 4) Sulitnya penerapan manajemen risiko secara profesional sesuai prinsip syariah.

Adapun kendala yang paling banyak menjadi problem utama perbankan syariah Kota Malang dalam implementasi manajemen risiko adalah kurangnya sumber daya yang berpengalaman dan tingginya biaya pengelolaan keuangan secara profesional sesuai prinsip syariah.

\section{Kesimpulan}

Berdasarkan rumusan masalah, paparan dan analisis data di atas, maka kesimpulan dalam penelitian ini dikontruksikan dalam tiga butir pernyataan sebagai berikut: 1) Implementasi prinsip bagi hasil dalam produk-produk pembiayaan dengan akad mudharabah dan musyarakah di perbankan-perbankan syariah Kota Malang belum semuanya sesuai syariat Islam sebagaimana fatwa DSN-MUI, karena lebih kurang $20 \%$ masih bertentangan dengan fatwa DSN-MUI, seperti masih adanya sebagian perbankan syariah di Kota Malang yang memperlakukan dana pembiayaan yang diberikan kepada nasabah bukan sebagai modal, tetapi sebagai piutang/ hutang dan bagi hasil yang bukan dengan persentase, tetapi nominal; 2) Implementasi manajemen risiko dalam produk-produk pembiayaan perbankan syariah di Kota Malang secara umum sudah sesuai 
dengan regulasi Bank Indonesia berupa Peraturan Bank Indonesia (PBI) nomor 13/23/PBI/2011 tentang "Penerapan Manajemen Risiko Bagi Bank Umum Syariah Dan Unit Usaha Syariah", walau ada beberapa kelemahan dalam implementasi manajemen risiko yang jadi fokus dalam penelitian ini, yaitu: risiko kredit (pembiayaan), risiko hukum dan risiko investasi, karena beberapa perbankan syariah di Kota Malang pernah mengalami ketiga risiko tersebut; 3) Adapun kendala-kendala yang dihadapi perbankan syariah Kota Malang dalam mengimplementasikan prinsip bagi hasil dalam produk-produk pembiayaan dengan akad mudharabah dan musyarakah dapat disimpulkan menjadi tiga kendala utama, yaitu: a) rendahnya pemahaman dan pengetahuan masyarakat tentang pembiayaan dengan akad mudharabah/ musyarakah; b) tingginya biaya pengelolaan keuangan secara profesional yang sesuai prinsip syariah dan; c) minimnya dukungan pemerintah. Sedangkan kendala-kendala yang dihadapi perbankan syariah Kota Malang dalam mengimplementasikan manajemen risiko di perbankan syariah Kota Malang adalah terkendala dalam dua hal pokok, yaitu: a) kurangnya sumber daya yang berpengalaman dan b) tingginya biaya pengelolaan keuangan secara profesional sesuai prinsip syariah.

\section{Daftar Pustaka}

Arfan, Abbas. 2012. Kaidah-Kaidah Fiqh Muamalah dan Aplikasinya dalam Ekonomi Islam dan Perbankan Syariah. Jakarta: Direktorat Pendidikan Tinggi Islam-KEMENAG RI.

Anderson, J.N.D. 1994. Islamic Law in The Modern World (Hukum Islam di Dunia Modern), terj. Machnun Husein. Yogyakarta: Tiara Wacana, cet. I.

Bank Indonesia, Statistik Perbankan Syariah; Oktober 2013, dalam www.bi.go.id , 2008. Kodifikasi Produk Perbankan Syariah, Direktorat Perbankan Syariah Bank Indonesia. 
, Peraturan Bank Indonesia Nomor 8/4/PBI/2006 tentang Pelaksanaan Good Corporate Governance bagi Bank Umum.

, Peraturan Bank Indonesia Nomor 11/33/PBI/2009 tentang Pelaksanaan Good Corporate Governance bagi Bank Umum Syariah (BUS) dan Unit Usaha Syariah (UUS).

, Peraturan Bank Indonesia (PBI) nomor 13/23/ PBI/2011 tentang Penerapan Manajemen Risiko Bagi Bank Umum Syariah Dan Unit Usaha Syariah.

Bungin, Burhan. 2001. Metodologi Penelitian Kualitatif. Jakarta: Rajawali Pers.

Dewan Syariah Nasional. 2001. Himpunan Fatwa Dewan Syari'ah Nasional Untuk Lembaga Keuangan Syari'ah, Ed. 1, Diterbitkan atas Kerjasama Dewan Syari'ah Nasional-MUI dengan Bank Indinesia.

Echols, John M. dan Hassan Shadily. 1995. Kamus Inggris Indonesia. Jakarta: PT. Gramedia.

Falah, Syamsul. 2003. Pola Bagi Hasil pada Perbankan Syari'ah, Makalah disampaikan pada seminar ekonomi Islam, Jakarta, 20 Agustus 2003.

Fatwa DSN-MUI No. 07/DSN-MUI/IV/2000 tentang pembiayaan mudharabah (Qiradh).

Fatwa DSN-MUI No. 08/DSN-MUI/IV/2000 tentang pembiayaan musyarakah.

Iska, Syukri. 2012. Sistem Perbankan Syariah di Indonesia dalam Perspektif Fikih Ekonomi. Yogyakarta: Fajar Media Press.

Jazuni. Legislasi Hukum Islam. 2005. Bandung: Citra Aditya Bakti.

Moleong. 2001. Metodologi Penelitian Kualitatif. Bandung: PT Remaja Rosda Karya.

Muhammad. 2002. Manajemen Bank Syariah. Yogyakarta: UPP AMP YKPN. 
Mujahidin. 2010. Prosedur Penyelesaian Penyelesaian Sengketa Ekonomi Syariah di Indonesia. Bogor: Ghalia Indonesia.

Mulyani, Sri. 2012. Implementasi Manajemen Risiko Pembiayaan dalam Upaya Menjaga Likuiditas Bank Syariah (Studi pada PT Bank Syariah Mandiri Cabang Malang), Skripsi. Malang: UIN Maulana Malik Ibrahim, Fakultas Ekonomi.

Pass, Cristopher dan Bryan Lowes. 1994. Kamus Lengkap Ekonomi. Jakarta: Erlangga.

Ruhiatudin, Budi. 2009. Pengantar Ilmu Hukum. Yogyakarta: Teras, cet. I.

Rustam, Bambang Rianto. 2013. Manajemen Risiko Perbankan Syariah di Indonesia. Jakarta: Salemba empat.

Soekanto, Soerjono. 1986. Pengantar Penelitian Hukum, Jakarta: UI Press, cet. III.

Sugiyono. 2009. Metode Penelitian Kuantitatif, Kualitatif dan R\&D. Bandung: Alfabeta, cet. VIII.

Tim Pengembangan Perbankan Syariah IBI. 2001. Konsep, Produk dan Implementasi Operasional Bank Syari'ah. Jakarta: Djambatan.

Thayalisa,Teguh. 2012. Proses Pelaksanaan Pembiayaan Mudharabah dan Perhitungan Bagi Hasil (Studi Pada PT.BPRS Bumi Rinjani Batu, Skripsi. Malang: UIN Maulana Malik Ibrahim, Fakultas Ekonomi.

UU No. 12/2011 tentang Pembentukan Peraturan PerundangUndangan.

UU No. 10/2004 tentang Pembentukan Peraturan PerundangUndangan.

Wafa, M. Ali. 2012. Perhitungan Nisbah Bagi Hasil Dalam Pembiayaan Mudharabah Pada PT. Bank Syari'ah Mandiri Cabang Malang, Skripsi. Malang: UIN Maulana Malik Ibrahim, Fakultas Ekonomi. 
Abbas Arfan, Saifullah, Fakhruddin

Zamroni. 1992. Pengantar Pengembangan Teori Sosial. Yogyakarta: Tiara Wacana. 